Klain, G. J., Vaughan, D. A. \& Vaughan, L. N. (1962). F. Nutr. 78, 359.

Kleiber, M. (1945-6). Nutr. Abstr. Rev. I5, 207.

Kleiber, M., Boelter, D. D. \& Greenberg, D. M. (1940). F. Nutr. 19, 5 I 7.

Krebs, H. A. (1960). Arzneimittel-Forsch. 10, 369.

Kriss, M., Forbes, E. B. \& Miller, R. C. (1934). f. Nutr. 8, 509.

Liang, C.-C. (1962). Biochem. F. 82, 429.

Lohmann, K. \& Schuster, P. (1937). Biochem. Z. 294, 188.

Mayes, P. A. (I959). Biochem. 7. 71, 459.

Nehring, M. \& Schiemann, R. (I96I). Int. Congr. Anim. Prod. vils, Hamburg, Vol. 3, p. 242.

Pecora, L. J. \& Highman, B. (1953). F. Nutr. 5r, 2 r9.

Peters, R. A. (1936). Lancet, i, I I6r.

Ritzman, E. G., Colovos, N. F., Keener, H. A. \& 'Teeri, A. E. (I945). Tech. Bull. N.H. agric. Exp. Sta. no. 87 .

Salem, H. M. (1954). Biochem. F. 57, 227.

Stewart, H. B. \& Young, F. G. (I959). Biochem. F. 72, 60.

van Eys, J. (1961). F. Nutr. 73, 403.

van Eys, J., Judge, M. A., Judd, J., Hill, W., Bozian, R. C. \& Abrahams, S. (1962). F. Nutr. 76, 375.

Vaughan, D. A. \& Vaughan, I. N. (1957). F. Nutr. 63, 417.

Vaughan, D. A. \& Vaughan, L. N. (1959). \%. Nutr. 68, 485 .

Vaughan, D. A. \& Vaughan, L. N. (1960). F. Nutr. 70, 77.

Vaughan, D. A. \& Vaughan, L. N. (I96r). F. Nutr. 73, 53 .

Voris, L., Black, A., Swift, R. W. \& French, C. E. (1942). J. Nutr. 23, 555 .

Voris, L. \& Moore, H. P. (I943). F. Nutr. 25, 7.

Wright, R. C. \& Scott, E. M. (1954). F. biol. Chem. 206, 725.

\title{
Dietary factors influencing nitrogen balance
}

By D. S. Miller, Queen Elizabeth College, University of London, London, $W 8$ and P. R. Payne, Human Nutrition Research Unit, National Institute for Medical Research, The Ridgeway, Mill Hill, London, $\mathrm{NW}_{7}$

It is the purpose of this paper to provide, in so far as it is possible, an integrated view of the interrelationships between nutrients as they affect nitrogen balance. The literature abounds with data described in qualitative terms and an attempt has been made here to fit them into a unified scheme. In doing so we may have been guilty of oversimplification, but such generalizations are valuable in that they can lead to the quantitative solution of practical nutritional problems, for example that of (I) the best utilization of limited supplies of foodstuffs to meet the needs of the vulnerable groups of a population which has a low purchasing power, or (2) that of the design of least-cost diets for animal production, particularly for pigs and poultry.

\section{List of terms used}

$\triangle B=$ nitrogen balance in $\mathrm{mg} / \mathrm{day} \mathrm{kg}^{0.73}$ body-weight

$I=$ nitrogen intake in $\mathrm{mg} / \mathrm{day} \mathrm{kg}^{0.73}$ body-weight $=0 .{ }_{4} \mathrm{PC}$

$\Theta=$ net protein utilization (NPU) expressed as a fraction

$M=$ nitrogen used for maintenance $=250 \mathrm{mg} \mathrm{N} /$ day $\mathrm{kg}^{\mathbf{0 . 7 3}}$ body-weight

$S=$ protein score expressed as a fraction

$k=$ constant $=0.019$

$P=$ protein calories as $\%$ of total calories

$C=$ calorie intake in $\mathrm{kcal} / \mathrm{day} \mathrm{kg}^{\mathbf{0 . 7 3}}$ body-weight

$C_{\mathrm{B}}=$ energy for basal metabolism $=70 \mathrm{kcal} /$ day $\mathrm{kg}^{0.73}$ body-weight 
In quantitative terms $\mathrm{N}$ balance $(\triangle B)$ will depend upon the $\mathrm{N}$ intake $(I)$, the efficiency with which it is used $(\Theta)$ and the amount of inevitable $\mathrm{N}$ loss $(M)$. Thus:

$$
\triangle B=I \Theta-M \text {. }
$$

In those countries with staples such as cassava, plantain or sago positive balances may not be achieved because the protein intake is low: a good deal of emphasis has been placed on the need to consume proteins of high biological value, but of first importance is the consumption of enough protein. The efficiency of utilization of dietary $N(\Theta)$ is the proportion of the intake of $N$ that is retained, i.e. net protein utilization (NPU) (Miller \& Payne, I96ra): it may be measured by the balance technique or by body analysis. The factor $M$ represents inevitable $\mathrm{N}$ losses, which are met by diets providing the maintenance requirements of protein. Most authorities consider $M$ to be a constant related only to body-weight and we have used a value of $250 \mathrm{mg} \mathrm{N} /$ day $\mathrm{kg}^{0.73}$ body-weight, which is supported by the data in Table $\mathrm{I}$.

Table I. Inevitable nitrogen losses

\begin{tabular}{|c|c|c|c|}
\hline & $\begin{array}{c}\mathrm{mg} \mathrm{N} / \mathrm{day} \\
\mathrm{kg}^{0.73} \\
\text { body-weight }\end{array}$ & Reference & Species \\
\hline $\begin{array}{c}\text { Endogenous } \\
\text { (urinary) }\end{array}$ & 146 & Brody ( 1945$)$ & All \\
\hline $\begin{array}{l}\text { Metabolic } \\
\text { (faecal) } \\
\text { Integumental }\end{array}$ & 54 & Martin \& Robison (1922) & Man \\
\hline (skin and hair) & 20 & Voit (I930) & Man \\
\hline Sweat & $\left\{\begin{array}{l}\operatorname{Min}=15 \\
\operatorname{Max}=I 70\end{array}\right.$ & $\begin{array}{l}\text { Mitchell \& Hamilton (1949) } \\
\text { Consolazio, Nelson, Matoush, Harding \& } \\
\text { Conham (1963) }\end{array}$ & $\begin{array}{l}\text { Man } \\
\text { Man }\end{array}$ \\
\hline Total & 250 & $\left\{\begin{array}{l}\text { Chittenden (1905) } \\
\text { Miller \& Payne (I962) } \\
\text { Goettsch (195I) }\end{array}\right.$ & $\begin{array}{l}\text { Man } \\
\text { Rat and pig } \\
\text { Rat }\end{array}$ \\
\hline
\end{tabular}

\section{Factors influencing the efficiency of utilization of dietary $N(\Theta)$}

A complete survey of all influences would include chronic undernutrition, infection, injury, stress and many others beyond the scope of this paper. Of the dietary factors, the most important are: (a) the amino acid composition of the protein, (b) the protein concentration, (c) the calorie intake, (d) the level in the diet of minerals, (e) the level in the diet of vitamins, and also (f) the spacing of meals. These we have considered in detail.

Amino acid composition. With the work of Willcock \& Hopkins (1 906) and Osborne (1907) the concept was established that the nutritive value of proteins could be interpreted in terms of amino acid composition, or in the light of more recent work in terms of their content of essential amino acids. Proteins are given a score based upon the content of that essential amino acid present in the least proportion in relation to a reference pattern. Difficulties are involved in both the chemical analysis and the selection of an appropriate scoring pattern. In the original paper by Block $\&$ Mitchell (1946-7) the amino acid content of egg protein was taken as a standard. Unfortunately there is no agreement as to the precise composition of egg protein, nor is it 
certain that this standard does not contain excessive proportions of some essential amino acids (Bender, I96I). In view of these difficulties Fisher (1954) has derived figures from other proteins. An alternative approach was made by FAO (1957), who derived a pattern from a consideration of the amino acid requirements of man. This pattern is widely used but may contain too low a proportion of lysine (Joseph, Tasker, Joseph, Rao, Swaminathan, Sankaran, Sreenivasan \& Subrahmanyan i 962) and too much tryptophan (Swendseid, Watts, Harris \& Tuttle, I96r). However, as most human and animal diets are limited by the sulphur amino acids, the reference values for methionine and cystine are the most important. This fact and the difficulties of amino acid analysis have led to the proposal of deriving a score simply from the total sulphur content of a diet (Miller \& Donoso, I 963 ). When diets contain proteins that have been subjected to severe heat treatment, it is essential to determine the availability of the amino acids (Carpenter, I960; Ford, 1962).

The units in which any successful reference pattern of amino acids is expressed should be as a proportion of the total amino acids. In this way the level of nonessential amino acids required is implicitly stated: the importance of this has been emphasized by Snyderman, Holt, Dancis, Roitman, Boyer \& Balis (1962) who showed that in certain circumstances $\mathrm{N}$ balance can be improved by the addition of glycine or urea. M. Swaminathan ( 1963 , unpublished) showed that the difference in nutritive value between proteins having similar ratios of essential amino acids could be explained if their amino acid content were expressed per $\mathrm{g} N$.

Levels of amino acids other than the most limiting may affect protein utilization (Oser, 195I). Amino acid imbalance, antagonism and toxicity have been investigated by Harper ( $195^{8}$ ), who concludes ((USA) National Research Council, I963) that it is difficult to distinguish between their direct effects on $\mathrm{N}$ utilization and the indirect effect on food intake. It seems unlikely that amino acid imbalance is important in diets in practice.

At low levels of $\mathrm{N}$ intake there are discrepancies between protein score and measured efficiencies of protein utilization. Under these conditions the amount of amino acids entering the metabolic pool from the katabolism of tissue proteins is appreciable in relation to that from the food and it is the amino acid balance of the resultant mixture that determines the rate of protein anabolism. As the tissue proteins have a relatively high proportion of lysine they will supplement diets low in this amino acid; this would account for the positive NPU values obtained with diets totally deficient in lysine (Doell, I960). Similarly at low levels of protein intake the pool may be effectively supplemented with methionine (Allison, Anderson \& Seeley, I947). In both of these examples the protein score will underestimate $\Theta$, but since $I$ is small the effect on $\mathrm{N}$ balance is unimportant.

Protein concentration. It is often assumed that the amino acid pattern of protein is the only factor deciding the efficiency with which the $\mathrm{N}$ of whole diets is utilized; but Osborne, Mendel \& Ferry (1919) showed that, for any protein source, the protein efficiency ratio was not constant but rose to a maximum value with increasing protein concentration and then declined. More recently Forbes, Vaughan \& Yohe (1958) 
working with rats and Summers \& Fisher (rg6r) with chicks showed a linear correlation between the efficiency of utilization $(\Theta)$ of individual proteins and their concentration in the diet. Also, Mitchell (1923-4) showed that $\Theta$ depends upon protein concentration rather than on total intake, and later (Metta \& Mitchell, I956) that protein calories as a percentage of total calories is the best parameter. In describing a system for the prediction of the protein values of diets we (Miller \& Payne, $196 \mathrm{I} b$ ) assumed that the fraction of food protein diverted for energy is directly proportional to the concentration of protein calories $(P)$ in the diet. Thus:

$$
\Theta=S(\mathrm{I}-k P) \text {, }
$$

where $S=$ protein score and $k=0.019$. This hypothesis is based on a consideration of the principles of mass law; in this instance that the rates of oxidation of amino acids and glucose are simply proportional to their concentration at the cell. Alternative estimates of $\Theta$ may be obtained by making more complicated assumptions, which lead to curvilinear relationships that hold over a wider range of protein concentrations. Thus Morrison, Sabry, Gridgeman \& Campbell (r963) have proposed a logarithmic form, but perhaps a more accurate description would be one based upon a function of the type proposed by Michaelis \& Menten (I9I3). However, equation 2 is satisfactory over the range of protein concentrations found in practice.

Calorie intake. Animals given restricted amounts of food burn increasing amounts of protein for energy purposes (Allison, 1958). As one might expect in the life process, the demand for energy has precedence over other requirements. Often the quality of the protein consumed becomes unimportant and $\mathrm{N}$ balance depends solely upon the calorie intake, a point of practical importance when considering nutritional problems in some developing countries. Thus equation 2 will not apply when calorie intake is inadequate. We (Miller \& Payne, I 96 $c$ ) have explained this by assuming that the retention of $\mathrm{N}$ requires a fixed amount of energy (I $50 \mathrm{kcal} / \mathrm{g} \mathrm{N}$ ). This includes not only the stored energy of the protein but also 'the work aspect to growth' (Brody, 1945) analogous to 'that expended in rearranging the chairs in a room in which case the potential energy of the chairs, or the room, is not increased'. This assumption leads to an expression for $\Theta$ under conditions of calorie restriction:

$$
\Theta=\frac{6 \cdot 8\left(C-C_{\mathrm{B}}\right)}{I},
$$

where $C$ is the calorie intake and $C_{\mathrm{B}}$ is the energy required for basal metabolism ( 70 $\mathrm{kcal} /$ day $\mathrm{kg}^{0.73}$ ). It will be seen that here the efficiency of $\mathrm{N}$ utilization does not depend upon the protein score.

\section{$N$ balance experiments}

It is thus possible to evaluate the effect of amino acid composition, protein concentration and calorie intake on $\mathrm{N}$ balance. Clearly these must be considered together because of the interrelationships that exist between them and there are enough data in the literature to verify the general theory put forward here. The data are of the three main types which differ according to the factor held constant by the experimenter, e.g. protein concentration (Mitchell, 1923-4), calorie intake 
(Allison \& Anderson, 1945), or $\mathrm{N}$ intake (Munro, 1951). In reviewing this work Munro ( 1963 ) observed that an acceptable explanation of the action of energy intake on protein metabolism must provide a reason why the effects of protein and energy intake on $\mathrm{N}$ balance are sometimes independent and sometimes interdependent. This may be explained by inserting the two possible expressions for $\Theta$ (equations 2 and 3 ) in equation $I$.

From equations $I$ and 2 combined:

$$
\triangle B=0.4 S C P-0.0076 S C P^{2}-250 \text {. }
$$

Alternatively, from equations $I$ and 3 :

$$
\triangle B=6.8 C-726 \text {. }
$$

The lesser of the two values for $\mathrm{N}$ balance is the one that applies (Miller \& Payne, 1963). Fig. I shows the results of the three types of $\mathrm{N}$ balance experiments predicted from equations 4 and 5 , and these are substantially in agreement with those found in the literature. Section $A$ shows a model experiment used to determine $\mathrm{N}$ balance indices for two proteins. The slopes of the curves indicate the quality of the proteins used; they are not strictly linear, but in the region of negative balance they are practically so. In the region of positive balance the relationship is curvilinear. The second section of Fig. I shows graphically the results of an experiment for the determination of biological value by the balance-sheet method, in which some of the animals were given limited amounts of food. It will be seen that, although $\mathrm{N}$ equilibrium can be achieved by giving more of the poorer-quality protein, maximum rates of $\mathrm{N}$ gain can only be achieved with proteins of superior quality. In section $C$ the protein-sparing action described by Munro (1951) is illustrated. At low calorie intakes this amounts to $6.8 \mathrm{mg} \mathrm{N} / \mathrm{kcal}$, in agreement with the work of Calloway \& Spector (1955); at higher intakes the value is lower.

\section{Equivalence of energy-yielding nutrients}

In the above discussion, calorie intakes have been stated without reference to the specific nutrients from which the energy has been derived. Evidence showing the

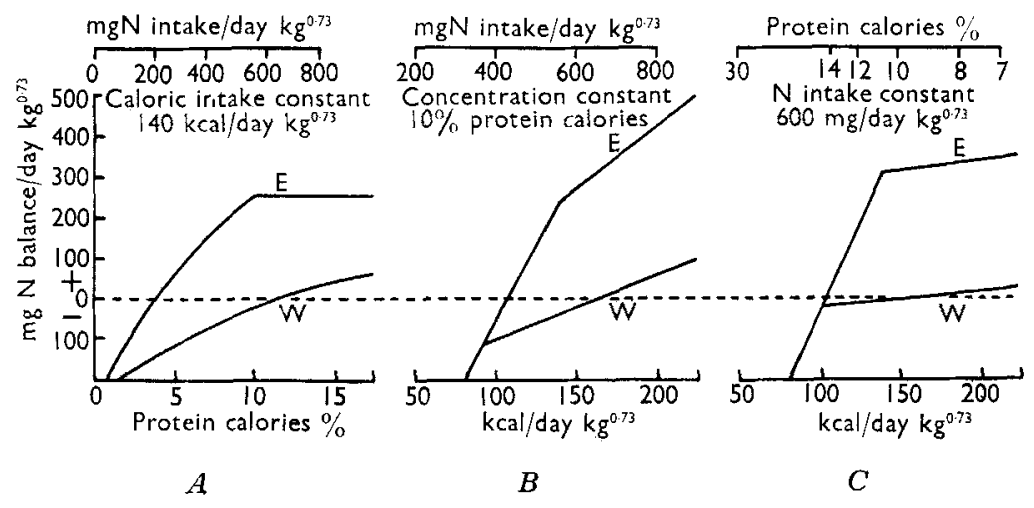

Fig. I. Diagram showing the results of three types of nitrogen balance experiment. E, egg protein; W, wheat gluten. 
general equivalence of metabolizable energy from fat, sugar, starch and alcohol is inconclusive; for example, differences between these nutrients are apparent in relation to ketosis (Woodyatt, I92 I) the requirements for riboflavine (Bro-Rasmussen, $1958 a, b$ ) and other B vitamins, serum albumin levels (Macdonald, 1962) and the yield of net energy (Forbes, Swift, James \& Bratzler, 1946). However, their effects on N balance in rats are equivalent calorie for calorie, although in man, especially when fasting, transient differences may be shown. In practical regimens it would appear that all sources of energy are equivalent in their effect on $\mathrm{N}$ balance. In his excellent review of this subject Munro (I 95 I) states that 'controlled feeding experiments do not suggest that protein utilization for growth is affected by alterations in the proportions of carbohydrates and fat in the diet'.

\section{Effect of other nutrients}

It is clear that any dietary deficiency that leads to poor growth will inevitably lead to an impairment of $\mathrm{N}$ balance. These effects may be simply due to loss of appetite or there may be reduced efficiency of food conversion. The effect of a deficiency of nutrients that are stored in the body takes longer to develop, is technically difficult to measure and may be obscured by other factors such as age; however, a deficiency of nutrients that cannot be stored may have an instantaneous effect. In the experiments of Morrison, Sabry \& Campbell (1962) an impaired utilization of the $\mathrm{N}$ of diets completely deficient in both vitamins and minerals was demonstrated. Other workers have studied the effects of deficiencies of individual minerals and vitamins.

Table 2. Effect of vitamin and mineral deficiencies on net protein utilization (NPU), calorie intake and nitrogen balance

\begin{tabular}{|c|c|c|c|}
\hline Diet & $\begin{array}{c}\mathrm{NPU}^{*}(\Theta) \\
(\%)\end{array}$ & $\begin{array}{r}\text { Calorie intake }(C) \\
\left(\mathrm{kcal} / \text { day } \mathrm{kg}^{0.73}\right)\end{array}$ & $\begin{array}{r}\mathrm{N} \text { balance }(\triangle B) \\
\left(\mathrm{mg} / \text { day } \mathrm{kg}^{0.73}\right)\end{array}$ \\
\hline I I \% Casein: complete & $65+1(50)$ & 185 & 275 \\
\hline without vitamins & $62 \pm 3(2)$ & I 55 & 172 \\
\hline without minerals & $40=1$ & 138 & -7 \\
\hline $\begin{array}{l}\text { without vitamins and } \\
\text { minerals }\end{array}$ & $40 \pm I \quad(3)$ & I 26 & -29 \\
\hline $21 \%$ Casein: complete & $52 \pm \mathbf{I} \quad(3)$ & 225 & $75^{\circ}$ \\
\hline without vitamins & $46 \pm 2$ (2) & 160 & 371 \\
\hline without minerals & $23 \pm 3$ & 130 & 0 \\
\hline $\begin{array}{l}\text { without vitamins and } \\
\text { minerals }\end{array}$ & $23 \pm 3$ & I I 8 & -24 \\
\hline without $\mathrm{Na}$ & $43 \pm 3 \quad(2)$ & 2 I 5 & 490 \\
\hline without $\mathrm{K}$ & $36 \pm 2 \quad(2)$ & 123 & 129 \\
\hline without $\mathrm{Ca}$ or $\mathrm{P}$ & $6 I \pm I$ & I 75 & 645 \\
\hline without trace elements $\dagger$ & $5 \mathbf{I}+\mathbf{I}$ & 175 & $5^{6} 5$ \\
\hline
\end{tabular}

* Mean value with standard error. Figures in parentheses are numbers of replicates.

$\uparrow \mathrm{Fe}, \mathrm{Mg}, \mathrm{Mn}, \mathrm{Cu}, \mathrm{Zn}, \mathrm{I}, \mathrm{F}$.

Table 2 provides a summary of some of our unpublished data and shows that a complete deficiency of all the mineral elements results in negative $\mathrm{N}$ balances, but diets of this type are not encountered in practice. However, diets low in either sodium or potassium could occur and these also lead to reduced $\mathrm{N}$ balances. There are two possible types of mechanism by which these factors may operate. (I) A direct 
reduction of net protein utilization $(\Theta)$. For example, the sodium-deficient rats maintained their food intake, but gave reduced values for $\Theta$. (2) An indirect reduction of $\Theta$ due to reduced food intakes, leading to increased protein katabolism for energy purposes (Miller \& Payne, r $96 \mathrm{rc}$ ). This is so in potassium deficiency.

The total deficiency of vitamins in the short-term experiments illustrated in Table 2 has little effect on $\Theta$ and the reduced $\mathrm{N}$ balances obtained are almost entirely due to reduced food intake. If it had been possible to continue these experiments for a longer period of time there might have been a more marked reduction in the net protein utilization. In the work of Naismith ( 1962 ) a complete deficiency of essential fatty acids was shown to produce a reduced $\mathrm{N}$ balance compared with that of pair-fed controls. Similarly Henry \& Kon ( 1956 ) showed that the biological value of casein was reduced for rats that were deficient in vitamin $B_{12}$.

\section{Timing of intake of nutrients}

Under practical conditions, man and animals are given spaced meals which frequently vary in composition. The application of experimental data derived with a constant feeding regimen treated as a continuous supply of nutrients needs qualification. Berg \& Rose ( 1929) demonstrated that, when a supplement of tryptophan was added to a deficient diet, the growth rate of rats decreased as the intervals between diet and supplement increased. A similar effect with rats has been shown by Cannon, Steffee, Frazier, Rowley \& Stepto (1947) working with diets based on pure amino acids, and by Geiger (1947) who separated the protein- and energy-containing components. However, the effect is less marked and largely transient in larger animals (Eggert, Brinegar \& Anderson, 1953) including man (Munro \& Wikramanayake, 1954). The differences between species in this respect should be considered in relation to the equivalence of time for each (Kleiber, 1962). This factor should also be taken into account when evaluating the results of experiments comparing animals eating separate meals or feeding continuously. It seems probable that the timing of nutrients is not of practical importance in large animals such as man.

\section{The prediction of $N$ balance}

By summarizing the influence of all the dietary factors it is possible to evaluate their relative importance in determining the protein value of regimens in practice. Table 3 shows the range of values of net dietary-protein calories $\%(P \Theta)$ and it is clear that the calorie intake and the concentration of protein in the diet are most important. Protein-rich foods should be directed to those populations consuming staple foods low in protein such as cassava, sago and plantain. Diets based on other

Table 3. Factors influencing the protein value of dietary regimens in practice

\begin{tabular}{lll}
\multicolumn{1}{c}{ Factor } & \multicolumn{1}{c}{ Practical range } & $\begin{array}{c}\text { Possible changes of } \\
\text { NDpCals } \%(\mathrm{P} \Theta)\end{array}$ \\
Amino acid pattern & 40-80 (score) & Twofold \\
Protein : calorie ratio & $5-50(\%$ protein calories) & Fourfold \\
Calorie intake & Famine-adequacy & Infinite \\
Mineral content & Deficient-adequacy & $25 \%$
\end{tabular}

$23(1) 2$ 
staples such as cereals and potatoes are adequate for all but the most vulnerable groups of the population provided they are consumed in adequate amounts.

From the preceding discussion it is clear that a good estimate of $\mathrm{N}$ balance may be calculated from a knowledge of the composition and quality of a given diet and, with certain additional assumptions, this knowledge can also lead to an estimate of weight gain and food conversion efficiency (Miller \& Payne, I963). The application to agricultural practice is obvious, not only in the economics of animal production but also in planning the diets of human populations by regulating agricultural policy. Such calculations are of value in designing regimens for different physiological purposes. Equations 4 and 5 have been used as the basis of computer programmes to deal with the problems involved in utilizing limited supplies of foodstuffs to meet the needs of a population and also to design diets for animal feeding (J. L. Joy, 1963 , personal communication). It may be that the precision of these calculations would not satisfy the experimentalist concerned with individual animals, but they are of value when applied to groups or populations and we hope they contribute to the understanding of the interrelationship of those nutrients that affect $\mathrm{N}$ balance.

\section{REFERENCES}

Allison, J. B. (1958). Ann. N.Y. Acad. Sci, 69, roo9.

Allison, J. B. \& Anderson, J. A. (1945). F. Nutr. 29, 4 I3.

Allison, J. B., Anderson, J. A. \& Seeley, R. D. (1947). J. Nutr. 33, 36r.

Bender, A. E. (г96r). Publ. nat. Res. Coun., Wash. no. 843, p. 407.

Berg, C. P. \& Rose, W. C. (1929). F. biol. Chem. 82, 479.

Block, R. J. \& Mitchell, H. H. (1946-7). Nutr. Abstr. Rev. 16, 249.

Brody, S. (1945). Bioenergetics and Growth. New York: Reinhold Publishing Corp.

Bro-Rasmussen, F. (1958a). Nutr. Abstr. Rev. 28, 1.

Bro-Rasmussen, F. (1958b). Nutr. Abstr. Rev. 28, 369.

Calloway, D. H. \& Spector, H. (1955). F. Nutr. 56, 533.

Cannon, P. R., Steffee, C. H., Frazier, L. J., Rowley, D. A. \& Stepto, R. C. (1947). Fed. Proc. 6, 390. Carpenter, K. J. (1960). Biochem. $\mathcal{F . 7 7 , 6 0 4 . ~}$

Chittenden, R. H. (1905), Physiological Economy in Nutrition. London: Heinemann.

Consolazio, C. F., Nelson, R. A., Matoush, L. O., Harding, R. S. \& Conham, J. E. (1963). F. Nutr. 79, 399.

Doell, B. H. ( 1960$)$. Retention of dietary nitrogen. Retention of incomplete amino acid mixtures. M.Sc. Thesis, University of London.

Eggert, R. G., Brinegar, M. J. \& Anderson, C. R. (1953). F. Nutr. 50, 469.

FAO (1957). FAO nutr. Stud, no. 16.

Fisher, R. B. (1954). Protein Metabolism. London: Methuen \& Co.

Forbes, E. B., Swift, R. W., James, W. H. \& Bratzler, J. W. (r946). Y. Nutr. 32, 387.

Forbes, R. M., Vaughan, L. \& Yohe, M. (1958). F. Nutr. 64, 291.

Ford, J. E. (1962). Brit. F. Nutr. 16, 409.

Geiger, E. (1947). F. Nutr. 34, 97.

Goettsch, M. (I95I). I. Nutr. 45, 609.

Harper, A. E. (1958). Ann. N.Y. Acad. Sci. 69, 1025.

Henry, K. M. \& Kon, S. K. (1956). Brit. F. Nutr. 10, 39.

Joseph, A. A., Tasker, P. K., Joseph, K., Rao, M. N., Swaminathan, M., Sankaran, A. N., Sreenivasan, A. \& Subrahmanyan, V. (1962). Ann. Biochem. 22, I I 3.

Kleiber, M. (1962). The Fire of Life. New York: Wiley.

Macdonald, I. (1962). F. Physiol. 160, 306.

Martin, C. J. \& Robison, R. (1922). Biochem. F. 16, 407.

Metta, V. C. \& Mitchell, H. H. (1956). F. Nutr. 59, 501.

Michaelis, L. \& Menten, M. L. (1913). Biochem. Z. 49, 1333.

Miller, D. S. \& Donoso, G. (1963). F. Sci. Fd Agric. 14, 345.

Miller, D. S. \& Payne, P. R. (Ig6ra). Brit. F. Nutr. I5, I I.

Miller, D. S. \& Payne, P. R. (1961 b). J. Nutr, 74, 413.

Miller, D. S. \& Payne, P. R. (r961c). F. Nutr. 75, 225. 
Miller, D. S. \& Payne, P. R. (1962). F. Nutr. 78, 255.

Miller, D. S. \& Payne, P. R. (1963). F. theoret. Biol. 5, 1398.

Mitchell, H. H. (1923-4). F. biol. Chem. 58, 905.

Mitchell, H. H. \& Hamilton, T. S. (1949). J. biol. Chem. r78, 345.

Morrison, A. B., Sabry, Z. I. \& Campbell, J. A. (1962). Canad. F. Biochem. 40, I663.

Morrison, A. B., Sabry, Z. I., Gridgeman, N. T. \& Campbell, J. A. (I 963). Canad. J. Biochem. 41, 275.

Munro, H. N. (195I). Physiol. Rev. 31, 449.

Munro, H. N. (1963). In Mammalian Protein Metabolism. [H. N. Munro and J. B. Allison, editors.] London: Academic Press Inc.

Munro, H. N. \& Wikramanayake, T. W. (1954). F. Nutr. 52, 99.

Naismith, D. J. (1962). Y. Nutr. 77, 381 .

National Research Council (1963). Evaluation of Protein Quality. Publ. nat. Res. Coun. Wash, no. I 100.

Osborne, T. B. (1907). Publ. Carneg. Instn, no. 84 .

Osborne, T. B., Mendel, L. B. \& Ferry, E. L. (1919). F. biol. Chem. 37, 223.

Oser, B. L. (195 1). F. Amer. diet. Ass. 27, 396.

Snyderman, S. E., Holt, L. E. Jr., Dancis, J., Roitman, E., Boyer, A. \& Balis, M. E. (1962). Y. Nutr. 78,57 .

Summers, J. D. \& Fisher, H. (196I). F. Nutr. 75, 435.

Swendseid, M. E., Watts, J. H., Harris, C. L. \& Tuttle, S. G. (1961). F. Nutr. 75, 295.

Voit, E. (1930). Z. Biol. 72, 549.

Willcock, E. G. \& Hopkins, F. G. (1906). \%. Physiol. 35, 88.

Woodyatt, R. T. (192 I). Arch. intern. Med. $28,125$.

\section{Nutrient interrelationships of the fatty acids}

By J. M. R. Beveridge, Department of Biochemistry, Queen's University, Kingston, Ontario, Canada

Any attempt to discuss in a definitive manner the nutrient interrelationships of the fatty acids is seriously hampered owing to a variety of reasons. These substances have been fed in the free form or as the methyl, ethyl, or simple glyceryl esters and the effects observed have been taken to reflect those of the respective fats and oils in which these fatty acids occur. It is not known, however, to what extent the nutritive effects of these compounds can be equated with those of the same acid as a residue of a natural triglyceride. Adding to the complexities of this problem is the recent finding by Dhopeshwarkar \& Mead (1962) that, at least in the guinea-pig, there is an endogenous production of methyl esters of the fatty acids. Many of the experiments described in the literature have involved a comparative study of the nutritive properties of various fats and oils differing in their fatty acid composition. All too frequently research workers have attributed any nutritional effects observed to differences in concentration of a group of fatty acids or indeed of a single fatty acid, ignoring or at least discounting the possible influence of the other differences in fatty acid composition of the fats under study. In addition, the effects of the nonglyceride components have been almost completely overlooked by many investigators. Usually the experimental conditions permit well-founded conclusions on the nutritive effects of dietary fat, but only an intelligent guess can be made concerning the probable role of the component fatty acids. With these limitations and qualifications in mind, let us now turn to an examination of some of the reports in the literature on this subject. This presentation makes no pretence of being encyclopaedic, and certain well-established interrelationships will not be discussed. 